\title{
New distribution reports of Rhagomys rufescens (Rodentia: Sigmodontinae) Thomas, 1886
}

\author{
Caryne Aparecida de Carvalho Braga* and Maria Rita Silvério Pires
}

\author{
Universidade Federal de Ouro Preto, Departamento de Evolução, Biodiversidade e Meio Ambiente, Laboratório de Zoologia dos Vertebrados, \\ Campus Morro do Cruzeiro. CEP 35400-000. Ouro Preto, MG, Brasil. \\ * Corresponding author. E-mail: carynebio@gmail.com
}

\begin{abstract}
Rhagomys rufescens is a rare, arboreal sigmodontine rodent endemic to the Brazilian Atlantic Forest biome. This species is known from eight localities in Brazil. Here we present a new report based on four individuals of this species registered in Serra do Ouro Branco, municipality of Ouro Branco (Minas Gerais, Brazil). One juvenile male, one adult male and two juvenile females were captured in pitfall traps during the rainy season, in a study of small mammal ecology. This is the first record for the Espinhaço Mountain range and the northernmost report for the species in this state, 85 km northeast of the last registered location.
\end{abstract}

Rhagomys rufescens (Thomas, 1886) is an enigmatic arboreal sigmodontine rodent classified at the suprageneric level as "incertae sedis" (Reig 1980; 1984; McKenna and Bell 1997; Smith and Patton 1999; Musser and Carleton 2005). This species was considered a "plesiomorphic Neotropical muroid", according to Voss (1993) and Steppan (1995). Although there is no consensus on its tribal position (Percequillo et al. 2004), some authors include Rhagomys in the tribe Thomasomyini, based on morphological characters (Pacheco 2003) or nuclear IRBP gene sequences (D'Elia et al. 2006; 2007). However, Testoni et al. (2010) were unable to determine the relationship between this species and others belonging to the Thomasomyini tribe using cytogenetic analyses.

Rhagomys rufescens is endemic to the eastern Brazilian Atlantic Forest morphoclimatic domain, being present in the states of Santa Catarina, São Paulo, Rio de Janeiro, Minas Gerais and Espírito Santo, and poorly represented in scientific collections and surveys (Steiner-Souza et al. 2008). Recently, Percequillo et al. (2011) found four molars of Rhagomys sp. in a single ocelot (Leopardus pardalis) scat sample from the municipality of Alta Floresta, state of Mato Grosso, Brazil. This specimen could be of the species $R$. rufescens but the authors were unable to confirm the identification.

Rhagomys rufescens was considered critically threatened by the IUCN in 1996, after 100 years without collecting reports, and it is currently regarded as near threatened (Geise et al. 2008). Information on geographic distribution is scarce and represented by about one or two individuals in each place, except for the municipality of Indaial, Santa Catarina, where 10 individuals were reported in an extensive work searching for this species (Steiner-Souza et al. 2008).

In this paper, we report the occurence of $R$. rufescens at the Serra do Ouro Branco, municipality of Ouro Branco, southeast Minas Gerais State, Brazil (Figure 1). This region is located in a transition between Cerrado and Atlantic
Forest domain, at the south of the Espinhaço mountain range. Our report occurred in an area of vegetation characterized as semi-deciduous mountain forest. A portion of the sampled locality is now inside a conservation area, the State Park of Serra do Ouro Branco.

This is the first record of this species in the Espinhaço mountain range, and the fourth and northernmost report for the species in the state of Minas Gerais. It is located about $85 \mathrm{~km}$ northeast of the last registered location in the Estação de Pesquisa, Treinamento e Educação Ambiental Mata do Paraíso (EPTEA Mata do Paraíso), in the municipality of Viçosa (Percequillo et al. 2004). The other known report for Minas Gerais is in the municipality of Poços de Caldas (Percequillo et al. 2004) and Parque Estadual Serra do Papagaio, municipality of Baependi (Passamani et al. 2011).

We carried a long term study on small mammals of the Serra do Ouro Branco from December 2006 to December 2010. In this study we used pitfall traps with drift fences, composed of buckets of $60 \mathrm{~L}$. The sampling was conducted for four nights per month. The traps were organized in two different ways along the study time.

From December 2006 to December 2009, the field work was conducted in one locality using three linear transects of 10 buckets each, perfoming 4440 traps / night. The transects were installed in three different habitats and distanced at least $500 \mathrm{~m}$ from each other. One of these habitats corresponded to the forest interior, another to an edge of the forest fragment near a cornfield, and the last one, to an edge near an area with a particular physiognomy of the brazilian savanna biome, known as "campo rupestre".

From January to December 2010, we sampled two other localities within the same forest spot. In each of these we placed three transects, one in the interior of the forest fragment, another at an edge near the road and the last one at an edge near a cornfield. Thus, the edge near a "campo rupestre" physiognomy was excluded in this 
second phase. All sampled localities distanced at least 1.5 $\mathrm{km}$ from each other. In this period we also changed the conformation of the pitfall traps from linear to Y-shaped transects. Each Y-shaped transect was composed of four buckets, one at each end, and one at the juncture of the Y. These transects were always installed in sets of three in each sampled habitat. This second phase of the study totaled 5184 traps/night, corresponding to 1728 in each locality, and 576 in each habitat type.

The collects were authorized by IBAMA NUFAS license under the number 482/06 and ICMBIO 21543-1. The animals were deposited in the Mammal Collection of the Laboratory of Vertebrate Zoology of the Universidade Federal de Ouro Preto (LZV-UFOP), with accession numbers 163R, 213R, 214R and 215R.

Rhagomys rufescens was captured only in two localities, and always in the interior of the forest fragment, over 40 $\mathrm{m}$ away from the nearest edge. These two localities were approximately $2.5 \mathrm{~km}$ distant to each other. In one of these localities, the canopy reaches 25 meters in height and the traps were located within ten meters of a stream $\left(20^{\circ} 29^{\prime} 43.16^{\prime \prime} \mathrm{S}, 43^{\circ} 36^{\prime} 26.71^{\prime \prime} \mathrm{W}, 1069\right.$ masl). In the other locality, there was no water source nearby and the canopy was lower, with 18 meters on average $\left(20^{\circ} 29^{\prime} 46.36^{\prime \prime} \mathrm{S}\right.$ and $43^{\circ} 37^{\prime} 23.97^{\prime \prime} \mathrm{W}, 935$ masl). This report of $R$. rufescens corroborates the pattern predicted by Steiner-Souza et al. (2008), in which this species seems to occur at altitudes above $500 \mathrm{~m}$, in transitional vegetation zones of montane forests.
TABLE 1. Body and cranial morphometric measurements, in millimeters, for the four individuals of Rhagomys rufescens collected in Serra do Ouro Branco, Minas Gerais, Brazil. The age class follows Voss (1991) and cranial measurements follow Pardiñas et al. (2009).

\begin{tabular}{|c|c|c|c|c|}
\hline & 163R & $213 \mathrm{R}$ & 214R & 215R \\
\hline Sex & $\mathrm{F}$ & M & $\mathrm{F}$ & M \\
\hline Head and body length & 85 & 83 & 82 & 98 \\
\hline Tail & 85 & 86 & 88 & 107 \\
\hline Hind Foot & 18 & 20 & 19 & 22 \\
\hline Ear length & 10 & 13 & 13 & 15 \\
\hline Age class & 1 & 2 & 2 & 4 \\
\hline Condylobasal length & 24.25 & 24.85 & 24.89 & 27.89 \\
\hline Occipital condyle width & 5.93 & 5.96 & 6.09 & 6.27 \\
\hline Diastema & 6.18 & 6.49 & 6.5 & 7.79 \\
\hline Palatal Bridge & 5.52 & 5.85 & 5.75 & 6.62 \\
\hline Incisive foramina length & 3.6 & 3.92 & 3.29 & 4.2 \\
\hline Incisive foramina width & 1.55 & 1.5 & 1.42 & 1.46 \\
\hline Upper molar row length & 4.45 & 4.46 & 4.43 & 4.82 \\
\hline M1 breadth & 1.69 & 1.3 & 1.39 & 1.32 \\
\hline Breadth between M1 & 4.81 & 4.91 & 4.85 & 5.09 \\
\hline Bullar length less tube & 3.77 & 3.79 & 3.72 & 3.72 \\
\hline Cranial height & 8.69 & 9.02 & 8.72 & 9.22 \\
\hline Rostral length & 8.35 & 8.54 & 8.38 & 10.14 \\
\hline Rostral width & 3.65 & 4.45 & 3.68 & 4.11 \\
\hline Least interorbital breadth & 4.86 & 4.97 & 5 & 5.06 \\
\hline Internal orbital length & 9.34 & 9.89 & 9.92 & 10.49 \\
\hline Zygomatic breadth & 12.96 & 14.08 & 13.81 & 15.49 \\
\hline Braincase width & 12.83 & 13.1 & 13.22 & 13.33 \\
\hline Zygomatic plate width & 3.31 & 3.13 & 3.5 & 3.58 \\
\hline Mandible height & 6.05 & 6.18 & 6.18 & 7.55 \\
\hline Mandible length & 12.97 & 13.49 & 13.4 & 15.34 \\
\hline
\end{tabular}

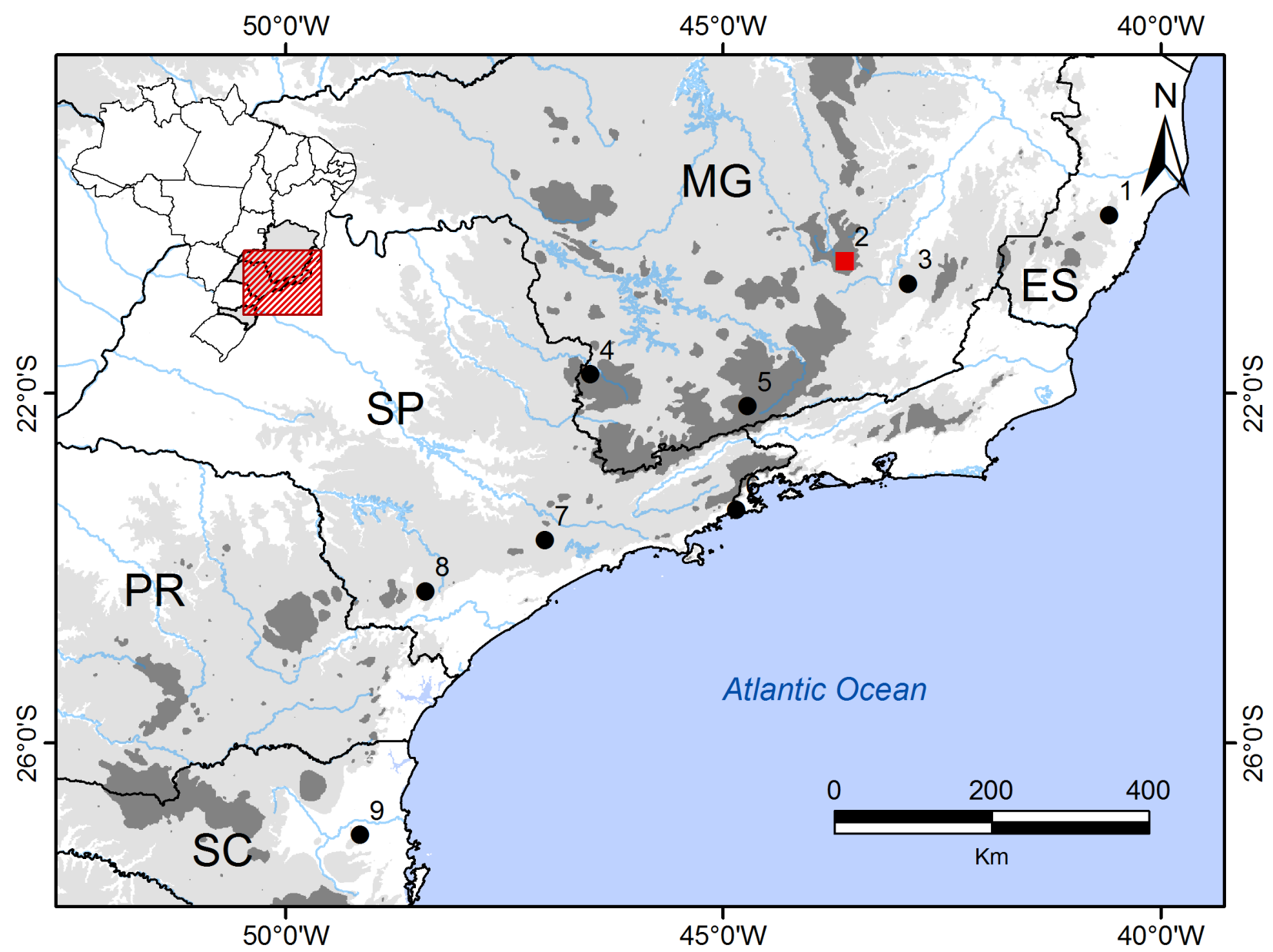

FIGURE 1. Distribution records of Rhagomys rufescens showing in red the locality for the new records presented here. 1- Santa Tereza (ES), 2- New record, Serra do Ouro Branco (MG) 3- EPTEA Mata do Paraíso (MG), 4- Poços de Caldas (MG), 5- Baependi (MG) 6- Ubatuba (SP), 7- Caucaia do Alto, 8- Ribeirão Grande (SP), 9- Indaial (SC). 
We captured one juvenile male in October 2010, one adult male in September 2010 and two juvenile females in February and December 2007. The morphometric data of these specimens followed Pardiñas (2008) and the age classes followed Voss (1991); they are shown in Table 1. The cranial measures seem to agree with the description of Percequillo et al. (2004), but our sample size and the high proportion of juveniles hindered us from making statistic analyses.

All captures of $R$. rufescens occurred on nights of heavy rain, with the animals being drowned in the water accumulated inside the buckets. The buckets were provided with a piece of Styrofoam in order to help the animals float, which unfortunately was not effective for this species. Umetsu et al. (2006) observed that the efficiency of the capture of rodents using pitfalls increases with precipitation. This seems to be true for R. rufenscens. In our study, the rain may have acted by stunning the animals, thereby allowing them to fall into the bucket full of water, and making it impossible to escape by jumping out of it.

Steiner-Souza et al. (2008) raise the question of whether $R$. rufescens is really a rare species or it is subsampled due to the type of trap used. The authors believe that pitfall traps are more efficient at capturing this species, because almost all specimens known were captured this way. However, in our four years of work, with a total effort of 9624 traps /night, only four individuals were collected, which leads us to believe that the species is really rare. If pitfall traps are the best kind to collect this species, maybe the buckets must be bigger to prevent them from escaping, because the specimens were captured only when the buckets were full of water. Thus, adults may have the ability to jump out of a $50 \mathrm{~cm}$ high bucket, which would be more difficult for young individuals, which correspond to the majority of the specimens captured in this study.

These records in a protection area are very important to $R$. rufescens conservation. Currently there are only three records of this species for Minas Gerais, and one of them, in Poços de Caldas, corresponds to an area under great impact due to bauxite mining (Percequillo et al. 2004). More studies need to be made in montane forests aimed at finding new populations of $R$. rufescens in Minas Gerais, so we can monitor it and better understand the requirements and particularities of this species.

ACKNOWLEDGMents: We would like to thank Y.L.R. Leite and L. P. Costa for the identification of the first individual captured, L. O. Drummond, A. R. Cruz, A. P. Magalhães, R. B. Leite and V. B. Pereira for the help in field work and laboratory procedures, M. R. Moura for making the map, the Graduate Program in Ecologia de Biomas Tropicais and UFOP for grants and logistics, and the FAPEMIG for financial support.

\section{Literature Cited}

D’Elia, G., L. Luna, E.M. Gonzalez and B.D. Patterson. 2006. On the Sigmodontinae radiation (Rodentia, Cricetidae): An appraisal of the phylogenetic position of Rhagomys. Molecular and Phylogenetics Evolution 38: 558-564.

D’Elia, G., U.F.J. Pardiñas, P. Teta and J.L. Patton. 2007. Definition and diagnosis of a new tribe of Sigmodontine rodents (Cricetidae: Sigmodontinae), and a revised classification of the subfamily. Gayana 71(2): 187-194.

IUCN 2011. IUCN Red List of Threatened Species. Version 2011.1. Eletronic database accessible at http://www.iucnredlist.org. Captured on 06 July 2011.

McKenna, M.C. and S.K. Bell. 1997. Classification of Mammals above the species level. New York: Columbia University Press. 631p.

Musser, G. and M.D. Carleton. 2005. Superfamily Muroidea. p. 894-1531. In D.E. Wilson and D.M. Reeder (ed.). Mammal Species of the World: A Taxonomic and Geographic Reference. 3rd edition. Baltimore: The Johns Hopkins University Press.

Pacheco, V.R. 2003. Phylogenetic analyses of the Thomasomyini (Muroidea, Sigmodontinae) based on morphological data. PhD. Thesis. NewYork: The City University of NewYork.

Passamani, M., R.A.S. Cerboncini and J.E. Oliveira. 2011. Distribution extension of Phaenomys ferrugineus (Thomas, 1894), and new data on Abrawayaomys ruschii Cunha and Cruz, 1979 and Rhagomys rufescens (Thomas, 1886), three rare species of rodents (Rodentia: Cricetidae) in Minas Gerais, Brazil. Checklist 7(6): 827-831.

Percequillo, A.R., P.R. Gonçalves and J.A. Oliveira. 2004. The rediscovery of Rhagomys rufescens (Thomas, 1886), with a morphological rediscription and comments on its systematic relationships based on morphological and molecular (cytochrome b) characters. Mammalian Biology 169: 238-257.

Percequillo, A.R., F.P. Tirelli, F. Michalski and E. Eizirik. 2011. The genus Rhagomys (Thomas 1917) (Rodentia, Cricetidae, Sigmodontinae) in South America: morphological considerations, geographic distribution and zoogeographic comments. Mammalia 75: 195-199.

Reig, O.A. 1980. A new fossil genus of South American cricetid rodents allied to Wiedomys, with an assessment of the Sigmodontinae. Journal of Zoology 192: 257-281.

Reig, O. A. 1984. Distribuição geográfica e história evolutiva dos roedores muroideos sulamericanos (Cricetidae, Sigmodontinae). Brazilian Journal of Genetics 8: 333-365.

Smith, M.F. and J.L. Patton. 1999. Phylogenetic relationships and the radiation of Sigmodontine rodents in South America: Evidence from cytochrome b. Journal of Mammalogy 6: 89-128.

Steiner-Souza, F., P. Cordeiro-Estrela, A.R. Percequillo, A.F. Testoni, and S.F. Althoff. 2008. New records of Rhagomys rufescens (Rodentia: Sigmodontinae) in the Atlantic forest of Brazil. Zootaxa 1824: 28-34.

Steppan, S.J. 1995. Revision of the tribe Phyllotini (Rodentia, Sigmodontinae), with a phylogenetic hypothesis for the Sigmodontinae. Fieldiana Zoology 180: 1-112.

Testoni, A.F., S.L. Althoff, A.P. Nascimento, F. Steiner-Souza and I.J. Sbalqueiro. 2010. Description of the karyotype of Rhagomys rufescens Thomas, 1886(Rodentia, Sigmodontinae) from Southern Brazil Atlantic forest. Genetics and Molecular Biology 33(3): 479-485.

Umetsu, F., L. Naxara and R. Pardini. 2006. Evaluating the efficiency of pitfall traps for sampling small mammals in the neotropics. Journal of Mammalogy 87: 757-765.

Voss, R.S. 1991. An introduction to the neotropical muroid rodent genus Zigodontomys. Bulletin of the American Museum of Natural History 210: 1-113.

Voss, R.S. 1993. A revision of the Brazilian muroid rodent genus Delomys with remarks on "Thomasomyine" characters. American Museum Novitates 3073: 1-44.

RECEIVED: November 2011

ACCEPTED: April 2012

Published ONLINE: June 2012

EDITORIAL RESPONSIBILITY: Mariano Soley 